\title{
Image, krop og maskulinitet Mediediskurser om skihoppere
}

\section{Af Gertrud Pfister og Rikke Schou Jeppesen}

\section{Indledning}

Skihop er i dag en typisk medie-sport, som ikke er baseret på en breddeidrætsbevægelse. På trods af det, tiltrækker de få specialister store skarer af tilskuere og journalister til deres konkurrencer.

De høje krav til færdighed og styrke kombineret med risikoen ved sporten har gjort skihop til en udpræget mandesport, som i hvert fald officielt udelukkede kvindelig deltagelse frem til 20001. Modstanden mod at acceptere kvinder i skihop er blandt andet forbundet med sportens og udøvernes image. Siden begyndelsen af det 19. århundrede var en skihopper indbegrebet af en 'rigtig mand'. Dette image har forandret sig igennem de seneste årtier. I dag er skihoppere berømtheder med skrøbelige egoer, tynde kroppe, et drenget udseende og fanklubber bestående af piger i teenagealderen.

Denne artikel beskriver og forklarer de forandringer, som sporten har gennemgået, og den indflydelse, som disse forandringer har haft på udøverne og på deres kroppe og images. Vi vil se på sammenhængen mellem på den ene side de images, udøverne skaber og iscenesætter om deres sportslige praksis og private liv, og på den anden side mediernes modtagelse, fortolkning og anvendelse af disse historier. Særligt fokus vil være på mediernes rolle i forhandlingen om og konstruktionen af ambivalente maskulinitetsformer.

\section{Køn og maskulinitetsformer til debat-teoretiske betragtninger}

Vi baserer analysen på en konstruktivistisk tilgang, som fanger de dynamikker, der er i spil i krydsfeltet mellem sport, udøver, medier og offentligheden $\mathrm{i}$ forbindelse med konstruktionen og forhandlingen af skihoppernes image, krop og maskulinitet. Tilgangen betragter også køn som socialt skabt og socialt forhandlet. Konstruktivismen forstår "gender as a process of social construction, a system of social stratification, and an institution that structures every aspect of our lives because of its embeddedness in the family, the workplace and the state as well as in sexuality, language and culture,$_{,}{ }^{2}$ og man kunne tilføje, at det ligeledes er tilfældet i sport. Køn har et biologisk fundament, men er også socialt og kulturelt betinget. Køn er ikke noget, vi har, men noget, vi $g ø r$, idet alle aktivt og til enhver tid i hverdagens interaktioner iscenesætter køn og er engageret $i$ at praktisere $k ø n$ (på engelsk: $»$ doing gender $\ll)$. At »gøre« eller praktisere køn - begge betegnelser vil blive brugt i artiklen - refererer til det aktive og handlende i kønskonstruktion. ${ }^{3}$ Køn skabes og for- 
handles i sociale kontekster ud fra en kulturelt bestemt kønsorden ${ }^{4}$ gennem kønsregimer, som omhandler idealer, normer og regler for kvinder og mænd og deres iscenesættelse. Sociologen Judith Lorber pointerer regimernes effektivitet og samtidige usynlighed:

»The division of society and our immediate social worlds by gender is so taken for granted that we rarely probe the processes that produce it. They are virtually invisible. Yet it is our actions and beliefs that construct the gendered social order.$^{5}$

Kroppen er formidler af iscenesættelse og praktisering af køn, og feministiske forskere var med særligt fokus på kvindekroppen de første til at stille skarpt på kroppens betydning, og de har udfordret mange bredt accepterede 'sandheder' om køn og krop. Mandekroppen og maskulinitetsformer har i modsætning hertil i mindre grad været genstand for forskning. I de seneste årtier har dog især sociolog Robert Connell og hans studier af maskulinitetsformer haft en stor indflydelse på kønsstudier og på forståelsen af køn som et socialt fænomen. ${ }^{6}$

Ifølge Connell er køn ikke kun socialt skabt og noget vi gør. Køn bliver også oplevet og fortolket gennem kroppen i bevægelse. Connell fremhæver begrebet 'social embodiment' (dansk: social kropsliggørelse) i kønnede processer:

»Bodies are both objects of social practice and agents in social practice. [...] The practices in which bodies are involved form social structures and personal trajectories which in turn provide the conditions of new practices in which bodies are addressed and involved «?
Med andre ord er kroppen og kropslige praksisformer på samme tid bærere og medskabere af sociale normer og fortolkninger og spiller dermed en aktiv rolle i sociale processer og i social interaktion. Ikke mindst i den medierede sport, hvor medierne tildeler udøverne stjernestatus, kommer den mandlige krop og maskulinitet i spil:

»The most visual public male body in contemporary society is arguably the sporting body, with its connotations of action, youth, strength, power, heterosexuality and performance ${ }^{8}$

Medierne har en central rolle i skabelsen og iscenesættelsen af sportsstjerner i forhold til køn, krop, seksualitet og livsstil, og ved at sætte fokus på mandlige sportsfolk og mandesport reproducerer medierne kønsforskelle og en hegemonisk maskulinitet. ${ }^{9}$ Kønskonstruktioner bliver imidlertid konstant udfordret, forhandlet, defineret og iscenesat afhængig af de specifikke omstændigheder, og de forandres og tilpasser sig nye situationer og sociale forventninger. Inden for sporten specielt drives disse forandringer af jagten på rekorder og de relaterede tekniske forbedringer. ${ }^{10}$ Skihop er et godt eksempel på, hvordan forandringsprocesser i sporten har påvirket udøverne og medierne i forhold til konstruktion, iscenesættelse og forhandling af køn. I den forbindelse er det nødvendigt at betragte den historiske udvikling.

Historisk baggrund:

Skihoppere som indbegrebet af maskulinitet

Skihop udvikledes sammen med skiløb i Norge i 1800-tallet. Skihopkonkurrencer 


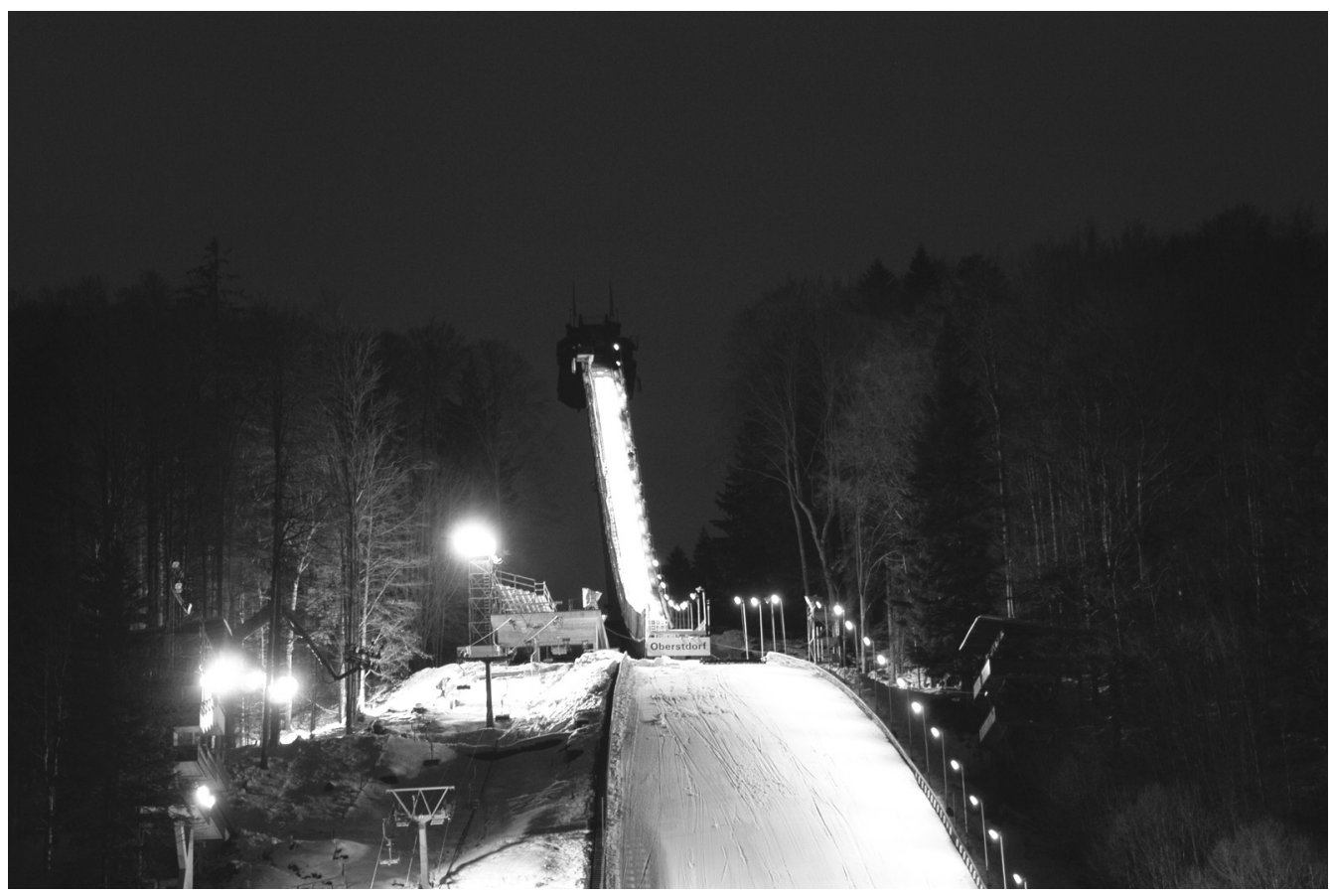

Skihopbakken i Oberstdorf badet i projektørlys (Ulrich Dorner fot., Rass und Dorner GmbH Kitzbïhel).

blev afholdt i forbindelse med alpine arrangementer i Oslo så tidligt som 1870'erne. ${ }^{11}$ Siden sin start har skihop været den mest spektakulære skisportsgren, og skihop blev anset som den ultimative skifærdighed. ${ }^{12}$ Tilskuere flokkedes i tusindvis langs hopbakkerne for at beundre de skihoppere, som mestrede den vovefulde bedrift at flyve gennem luften. Det tog ikke lang tid, førend pressen, populærlitteraturen og filmverdenen blev interesseret i denne sportsgren og begyndte at fremstille skihopperne som idoler for et bredt publikum. ${ }^{13}$ I både trivialog finkulturel litteratur symboliserede bjergbestigning, skiløb og skihop en meget tiltrækkende og moderne form for mandighed. Ved at udvise styrke, færdighed og mod og gennem at kropsliggøre 'sand maskulinitet' blev skihoppere hædret som helte af tilskuere og medier. I 1924 blev den første guldvinder i skihop beskrevet således:

»Den store og muskuløse Jakob Tullin Thams var en af heltene. [...] Når han ... satte af og hoppede langt gennem luften, fløj han også ind $i$ damernes hjerter; en sådan demonstration af mod og styrke fik dem til at tabe pusten $\omega^{14}$

Der Winter, et ledende tyske skisportstidsskrift på den tid, priste i forskellige sammenhænge skihop som den meste prestigefyldte vintersport. »Når de flyver gennem luften, giver disse modige sportsfolk indtryk af, at de har kontrol over både tid og rum. $\ll^{15}$ Styrke og beslutsomhed kombineret med ro og følelsesmæssig beherskelse gjorde skihopperen til arketypen på heroisk mandighed. ${ }^{16}$ 


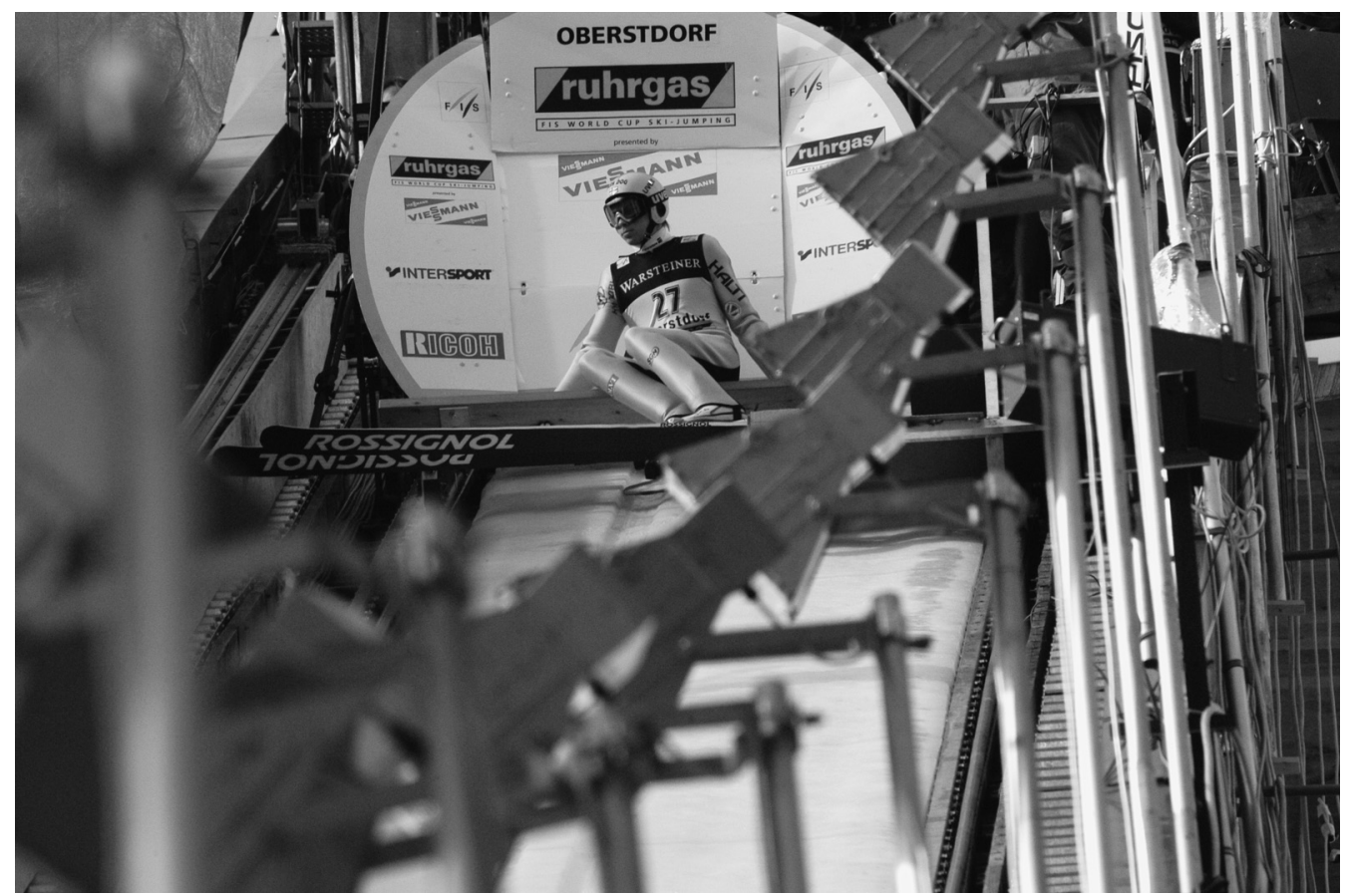

Skihopkonkurrence i Oberstdorf (Ulrich Dorner fot., Rass und Dorner GmbH Kitzbühel).

Skihop begyndte imidlertid at dale i popularitet efter 2. Verdenskrig, ikke mindst fordi det var umuligt at forbedre præstationerne på de eksisterende, relativt små ramper.

Skihop kæmpede sig dog tilbage til offentlighedens bevågenhed, med fornyet medieinteresse til følge, da en ny hoppestil dukkede op og resulterede $\mathrm{i}$ både fantastiske præstationer og forandringer i skihoppernes image. V-stilen blev skabt i 1980'erne af svenskeren Jan Boklöv, som ved et tilfælde fandt ud af, at han kunne hoppe længere, når han spredte skiene fortil, så de dannede et $\mathrm{V}$ i luften. I begyndelsen blev Boklöv straffet af dommerne med lave stilkarakterer, fordi han ikke holdt skiene parallelt som i den anerkendte teknik. Skiforbundet og dommerne mente, at hans stil ødelagde hoppets elegance og svævets skønhed. ${ }^{17}$ Men tilskuerne accepterede den nye uortodokse teknik, fordi den resulterede i nye rekorder, og dermed øgedes spændingen og begejstringen. Længden på Boklövs hop var så overbevisende, at andre udøvere forsøgte sig med den nye stil, hvilket medførte, at parallel-stilen og dens tilhængere i 1990'erne helt forsvandt fra skihop. ${ }^{18}$

Indtil 1980'erne havde styrke, kraft og afsættets timing været de vigtigste forudsætninger for et godt hop, hvilket betød, at det overvejende var høje og muskuløse mænd, der dominerede konkurrencerne. Vstilen revolutionerede skihoppernes kroppe og teknik, fordi den gav lette udøvere en fordel. Således er skihopperne blevet tyndere og tyndere - nogle endda i en grad, så de er blevet anorektikere. Men deres præstationer er blevet forbedret markant.

Jagten på nye rekorder og kravet om konstant forbedring af de sportslige præstatio- 


\begin{tabular}{|c|c|c|c|c|}
\hline & \multicolumn{2}{|c|}{ Hannawald } & \multicolumn{2}{|c|}{ Schmitt } \\
\hline & Individuel & Hold & Individuel & Hold \\
\hline OL & Sølv 2002 & $\begin{array}{l}\text { Sølv } 1998 \\
\text { Guld } 2002\end{array}$ & & $\begin{array}{l}\text { Sølv } 1998 \\
\text { Guld } 2002\end{array}$ \\
\hline VM & Sølv 1999 & $\begin{array}{l}\text { Guld } 1999 \\
\text { Guld } 2001 \\
\text { Bronze } 2001\end{array}$ & $\begin{array}{l}\text { Guld } 1999 \\
\text { Guld } 2001 \\
\text { Sølv } 2001\end{array}$ & $\begin{array}{l}\text { Bronze } 1997 \\
\text { Guld } 1999 \\
\text { Guld } 2001 \\
\text { Bronze } 2001 \\
\text { Sølv } 2005\end{array}$ \\
\hline $\begin{array}{l}\text { Skiflyvnings } \\
\text { VM }\end{array}$ & $\begin{array}{l}\text { Sølv } 1998 \\
\text { Guld } 2000 \\
\text { Guld } 2002\end{array}$ & & Sølv 2002 & \\
\hline
\end{tabular}

Kilde: http://de.wikipedia.org/wiki/Sven_Hannawald; http://de.wikipedia.org/wiki/ Martin_Schmitt (gennemset 13.03.08).

ner afstedkom tekniske og stilmæssige forandringer, som ændrede skihoppernes kroppe. I det følgende vises, hvordan de nye skihoppere præsenterer et nyt image, der både indbefatter skihoppernes forandrede kroppe og imødekommer publikums og mediernes forventninger. Medier og skihoppere samarbejder - $\mathrm{i}$ hvert fald $\mathrm{i}$ en vis udstrækning - i forhandlingen af skihoppernes image og deres praktisering af køn. Vores fokus i artiklen er på skihoppernes og mediernes interdependente konstruktioner af images og maskulinitetsformer.

\section{Mediereprosentation: skihoppere og ambivalent maskulinitet}

Undersøgelsen er baseret på en diskursanalyse af mediedækningen af de to mest berømte skihoppere i Tyskland; Martin Schmitt (født 1978) og Sven Hannawald (født 1974). Imellem 1999 og 2002 var de begge blandt verdens bedste skihoppere, og de blev på baggrund af deres sportslige succes hyldet og beundret af et stort publikum. Begge har vundet verdensmesterskaber og OL-medaljer. Desuden vandt Sven Hannawald i 2001/2002 - som den første og eneste skihopper nogensinde - alle fire konkurrencer i den berømte »Four Hills Tournament«. Deres vigtigste medaljer kan ses i Tabel 1.

Schmitts og Hannawalds succes har forandret skihopsportens og udøvernes image radikalt. De tiltrak nye fans til sporten, var efterspurgt af sponsorer og dukkede op i reklamer. I 2000 fik deres popularitet den private tyske tv-kanal RTL til at købe rettighederne til de mest attraktive skihopkonkurrencer. RTL udnævnte skihop til »Vintersportens Formel $1 \ll{ }^{19}$ Skihop var tilbage i offentlighedens søgelys, og Schmitt og Hannawald blev levende legender.

I det følgende præsenteres undersøgelsen af mediedækningen af Martin Schmitt og Sven Hannawald i udvalgte trykte tyske medier. Kilderne er samtlige artikler om skihop publiceret mellem 1998 og 2004 i Der Spiegel, Europa's største og mest ind- 
flydelsesrige nyhedsmagasin ( $\mathrm{N}=19)$. Derudover er alle artikler om Schmitt og Hannawald skrevet mellem 2000 og 2004 blevet analyseret i følgende aviser; Die Welt $(\mathrm{N}=24)$, en landsdækkende morgenavis med et oplag på omkring 200.000; Die Welt am Sonntag (Wams) $(\mathrm{N}=17)$; formiddagsavisen Bild $(\mathrm{N}=30)$ og dennes specialudgaver Bild am Sonntag (BamS) $(\mathrm{N}=11)$ og Sport Bild $(\mathrm{N}=8)$. Bild er den bedst sælgende avis $\mathrm{i}$ Europa og har verdens tredjestørste oplag. Die Welt har en seriøs skrivestil, mens Bilds artikler er korte, kontante og ofte under bæltestedet.

Metoden har været kvalitativ tekstanalyse. ${ }^{20}$ En række kategorier er blevet etableret induktivt ved hjælp af artiklerne fra Der Spiegel, og kategorierne er derefter blevet anvendt på artiklerne fra de øvrige aviser. Der Spiegel beskæftiger sig med nye trends og strømninger, med kontroversielle emner og sætter ofte dagsordenen for debatter om politiske, sociale og kulturelle tendenser i Tyskland. Derfor kan Der Spiegel bruges som 'lakmusprøve' til at identificere relevante og betydningsfulde problemstillinger. Skihop og fremstillingen af udøverne blev, trods vores formodninger om det modsatte, dækket meget ens i de forskellige aviser. I det mindste hvad angår det overordnede indhold og kategorier. Derved stemte de kategorier, som blev identificeret $i$ analysen af Der Spiegel ganske godt overens med indholdet i Die Welt og Bild.

Generelt fokuseres der i de analyserede artikler ikke på selve sportsbegivenheden, men i højere grad på udøvernes (privat)liv, krop, følelser samt deres op- og nedture. Meget få artikler giver informationer om tekniske detaljer som hoppet, landingen, hopbakkerne eller reglerne. I det følgende vil vi præsentere de mediediskurser, som blev udkrystalliseret i undersøgelsen. Det drejer sig om skihops betydning, om udøvernes udfordringer, om kropslige og psykiske aspekter og problemstillinger, om privatliv, om fankulturen og om deres stjernestatus. Alle diskurserne relaterer sig samtidigt til budskaber om skihoppernes maskulinitet.

\section{Skihops betydning: metaforer og kælenavne}

Skihop og ikke mindst skiflyvning vækker i artiklerne associationer til at "flyve som en fugl $\ll$ og »trodse tyngdeloven «. ${ }^{21}$ Hermed skiller skihoppere sig ud som mennesker, der tilsyneladende har opnået menneskehedens ældgamle drøm om at kunne flyve. Bild glorificerer endda et af Schmitts sejrshop som et »sveev til evigheden" og som at »lande på månen «.22 Men denne metafor påviser ambivalens idet at »flyve med fuglene« indebærer »at tage chancer [...] Under ideale vejrforhold nyder udøverne følelsen af at vaere som fugle. I dårligt vejr er de dødsens angst $\ll .{ }^{23}$ Glæden ved at flyve kan få udøveren til at glemme faren, men manglende koncentration kan straffes med et fald. Den mytiske figur, Ikaros, som betalte for sin overmodige flyvetur for tæt på solen med sit liv, bliver anvendt til at symbolisere fascinationen, faren og fordærvelsen i skiflyvning. ${ }^{24}$

I skiflyvning forenes menneskets gamle drøm om at flyve med sponsor- og TV-interesser. ${ }^{25}$ Kombineret med det potentielle (fatale) fald gør det skihop til spektakulær underholdning, som opfylder publikums sensationslyst og samtidigt fremkalder følelser af spænding og beundring.

Flyvemetaforen er også anvendt om udøverne, der hyldes som ørne med kælenavne som »leder-ørnen«, »super-ørnen" og »kongeørnen « ${ }^{26}$ Andre kælenavne som 


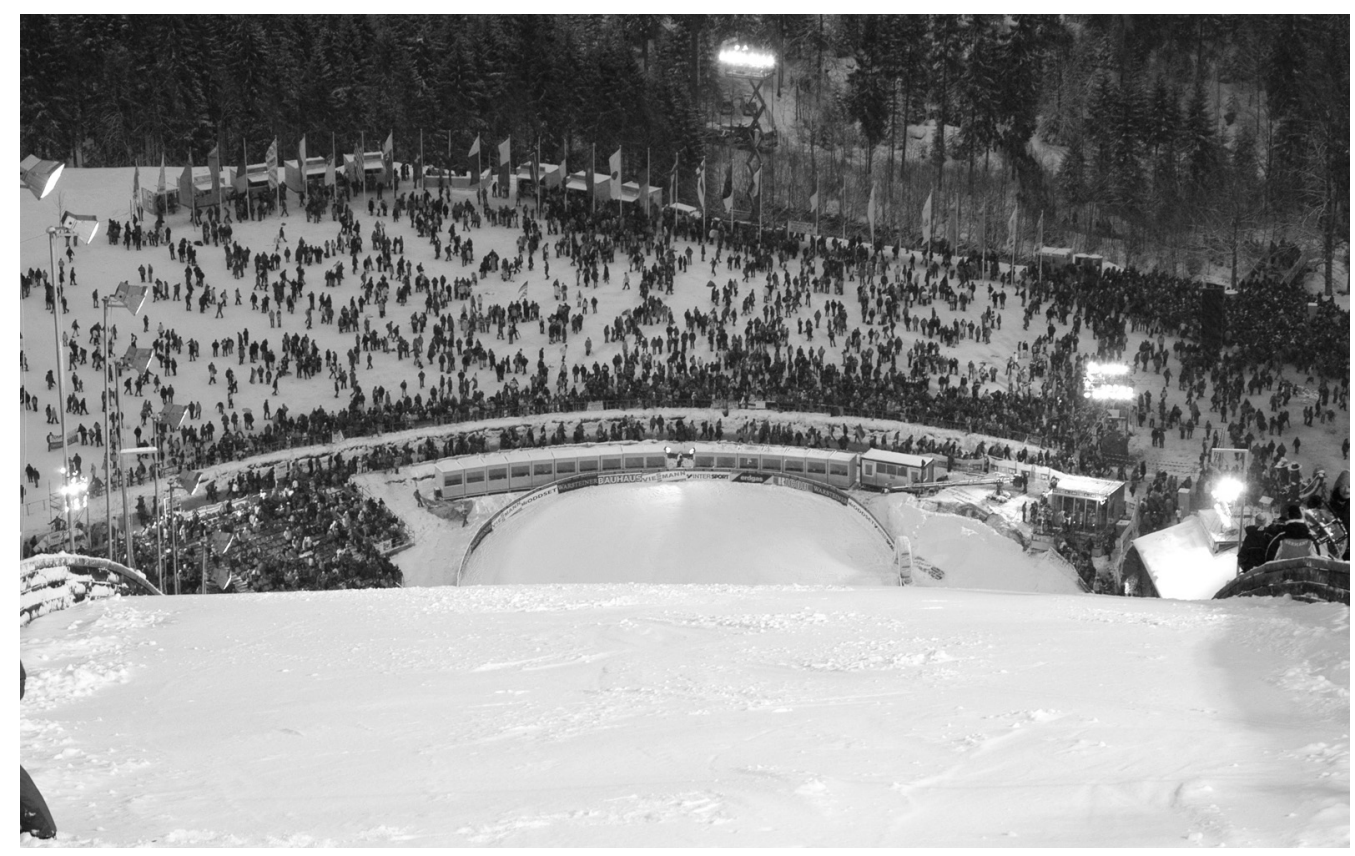

Et kik ud over skihopbakken i Oberstdorf (Ulrich Dorner fot., Rass und Dorner GmbH Kitzbühel).

»luftens konge«, »himlens mester« eller endog »den hoppende gud" indikerer, at udøverne opleves som helte. ${ }^{27}$ Den hyppige brug af "vores" indikerer national stolthed og giver læserne mulighed for at identificere sig med deres $»$ tyske idoler $«{ }^{28}$

Der er dog også kælenavne (eksempelvis »loppe og »sanglcerke«), som frem for at lede tanken hen på heltemodig mandighed hentyder til skihoppernes små og lette kroppe. Sven Hannawald omtales ofte med det tyske pigenavn »Hanni«. ${ }^{29}$ Sammen bliver Hannawald og Schmitt tit benævnt »Hanni und Nanni $\ll,{ }^{30}$ hvilket er den tyske titel på en berømt engelsk børnebog om to piger. ${ }^{31}$ Ofte bliver skihopperne udråbt som »teenageidoler«, "pigernes øjesten « eller »drengegruppen « med henvisning til deres reklametække og popularitet hos pigerne, hvilket samtidigt nedtoner deres sportslige præstationer. ${ }^{32}$ Navne som »vovehalse eller »vilde hunde« henviser til den risiko, de udsætter sig for, ${ }^{33}$ men disse navne bliver ofte brugt sammen med nedladende navne som »Hanni« eller »Luft Hanni«, som indeholder tvetydige budskaber, der reducerer skihoppernes heroiske udstråling. Skihoppernes image er meget dækkende sammenfattet af Der Spiegel til »de skrøbelige helte«. ${ }^{34}$

Skrøbelige helte: smukke, »æteriske $\operatorname{vrag} \ll{ }^{35}$

Skihoppernes kroppe og kropslige iscenesættelse fylder meget i medierne. Emner som skihoppernes udseende og vægt bliver brugt til at så tvivl om skihoppernes maskulinitet. Igen og igen skriver medierne om de to skihopperes gode udseende. Schmitt bliver kaldt »the beau« eller »James Dean«, mens Hannawald bliver idoliseret for sine »blå lady-killer eyes« med vendinger som "Et blik fra Hanni, gør hans kvindelige fans bløde $i$ knceene« ${ }^{36}$ Udøverne gør på deres 


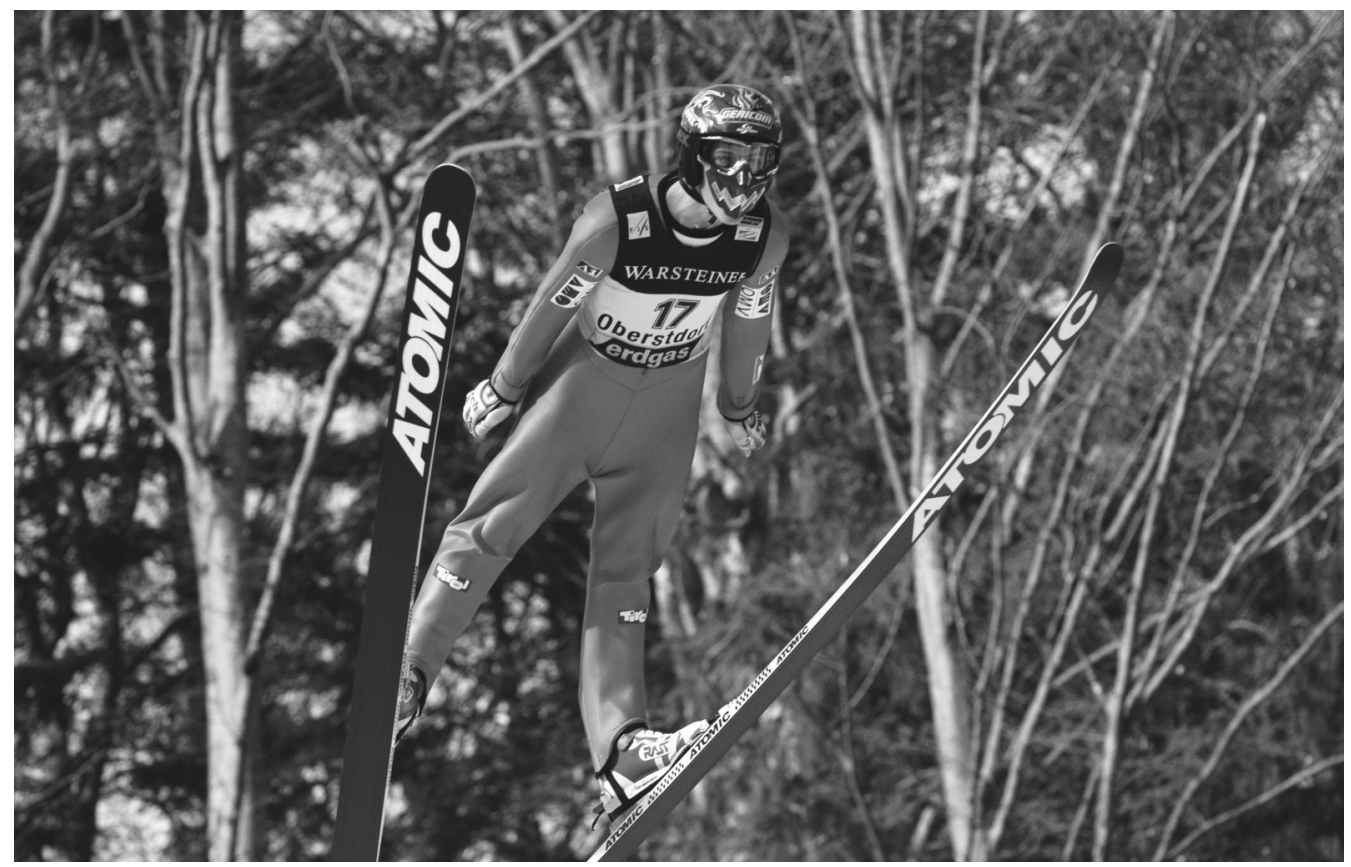

Skihopperne er i bogstaveligste forstand flyvende på skihopbakken i Oberstdorf (Ulrich Dorner fot., Rass und Dorner GmbH Kitzbühel).

side desuden alt for at forbedre deres fremtræden, fremhæve deres (gode) udseende og spille deres roller som mandlige skønheder. De farver håret rødt eller får striber i, bærer iøjnefaldende smykker og går i dyrt mærketøj. ${ }^{37}$ Ifølge Bild er Hannawald forfængelig - altid med gele i håret og duftende af Christian Diors parfume $»$ Higher ${ }^{38}{ }^{38}$ I et interview fortæller Hannawald at »Jeg bruger rensemalk. [...] Jeg kan lide at gå i laekkert tøj, og jeg synes, at folk i parfumereklamer er cool påklcedte. $\aleph^{39}$ Det viser, at de to skihoppere ikke følger (sportens) traditionelle maskulinitetsnormer, men skaber nye images og praktikker såsom deres åbenlyse fokus på udseende og hudpleje; images som defineres som feminine inden for de eksisterende kønsregimer. Men det kan de ikke gøre ustraffet, idet medierne beskriver heltenes »feminine vaner« med en blanding af beundring, forbavselse og forargelse. Det gælder også spørgsmålet om skihoppernes vægt. På grund af V-stilen bliver vægttab ikke blot et emne for udøverne, men også for medierne, som er ekstremt interesserede i skihoppernes vægt og ernæring. Især to nyhedsindslag sætter gang i debatten om skihoppernes vægtproblemer. I det første beskylder skihopperen Frank Löffler træneren for det tyske skihop-landshold for at have lagt pres på alle landsholdsdeltagerne for at få dem til at tabe sig. I den anden artikel luftes spekulationer om, at Hannawald lider af anoreksi, ${ }^{40}$ og et billede af ham i badebukser afslører en ekstremt tynd og udtæret krop. ${ }^{41}$ I anoreksidebatten bliver Hannawald og andre skihoppere beskrevet som skrøbelige, spinkle, »ceteriske vrag «. ${ }^{42}$

Selv de skihoppere, som ikke er decideret tynde, har ingen synlig og veldefineret muskulatur og lever derfor ikke op til de fremherskende mandeidealer. Den erken- 
delse kommer også til udtryk hos Hannawald, som i et interview drømmer om at have en krop som en bokser og tilføjer: »men, desvaerre, er det helt uegnet til min sportsgren ${ }^{43}{ }^{43}$

\section{Skrøbelige helte: skrøbelige sind?}

Et af mediedækningens omdrejningspunkter er Schmitt og Hannawalds følelsesliv; deres op- og nedture, skrøbelige nerver, frustrationer og deres sportslige og psykiske kriser, der ofte er tæt forbundne. »Det vaerste var, fortæller Hannawald til Bild, »at den sportslige nedtur påvirkede hele mit liv. Jeg kunne ikke sove om natten, fordi jeg altid toenkte på de dårlige hop «. ${ }^{44}$ Skihopperne lever under et enormt pres for at præstere og levere gode resultater. Men de lever også med presset fra skihopsportens iboende risiko. Selv om alvorlige ulykker er meget sjældne i skihop, er der konsensus blandt journalister, trænere og udøvere, om at skiflyvning er farligt, og at udøverne sætter helbred og i værste fald livet på spil i sporten. I sin beskrivelse af de ekstreme forhold i skihop, udtaler en holdkammerat til Hannawald og Schmitt, at »det er her moend skabes, ikke på fodboldbanen «. ${ }^{45}$ Samtidigt er angst et centralt tema, som nævnes i mange artikler; f.eks. skrives at \Angsten er der altid, når du flyver. Mod er at overvinde angsten «. ${ }^{46}$ Aviserne beskriver også de kropslige reaktioner på angst såsom stigende blodtryk, trangen til vandladning og det høje stressniveau, som hvert hop udløser. ${ }^{47}$

"Allerede om tirsdagen går hormonerne amok. Adrenalin-niveauet stiger blot ved tanken om det, der først starter to dage senere. Kroppen forbereder sig til at gå $i$ alarmberedskab. Torsdag formiddag $\mathrm{kl}$.
11.30 er sportsfolkene $i$ Planica... på den monstrøse ski-rampe. ${ }^{48}$

Mange skihoppere indrømmer åbent, at de er bange, og at de ryster af angst, specielt når de sidder på den lille bænk højt oppe på rampen og ser ned. På trods af, at Martin Schmitt i et interview påpeger, at han ikke er bange for at flyve ${ }^{49}$, indrømmer han andetsteds, at »når du står der en halv kilometer over dalen, har du gele i knoene og er dødsens angst ${ }^{50}$ Risiko- og angstdiskursen gør det på den ene side legitimt for udøverne at være bange, men på den anden side underminerer diskursen også billedet af den uovervindelige helt, som ikke viser følelser.

Det nævnes gentagne gange, at skiflyvning er et spørgsmål om vilje, og at succesen afhænger af psyken. ${ }^{51}$ I »skihop-lotteriet $\aleph^{52}$ er succes i langt højere grad end i andre sportsgrene betinget af skihoppernes mentale styrke, ud over faktorer som talent, færdigheder, udstyr, intensiteten af den personlige coaching og den konstante udvikling inden for teknologisk know-how. ${ }^{53}$ Det mentale pres bliver for stort for Hannawald og Schmitt, specielt i slutningen af deres karrierer. Hannawald oplever en stor krise i 2004 delvist på grund af hans psykologiske problemer, men også på grund af den massive opmærksomhed fra pressen. Det fortsatte stress, som bliver intensiveret af de stigende forventninger fra tilskuerne og fra massemedierne, udløser depression og udbrændthed hos Hannawald, hvilket tvinger ham til at gå i behandling på en psykiatrisk klinik. ${ }^{54}$ Hans sygdom og den efterfølgende "rejse tilbage til et normalt liv« (uden skihop) får næsten lige så stor opmærksomhed og mediedækning som hans tidligere sportspræstationer. Til slut i hans aktive karriere skriver Sport Bild om ham: »Hoengende skuldre, et tomt blik og hule kinder. Tysk- 


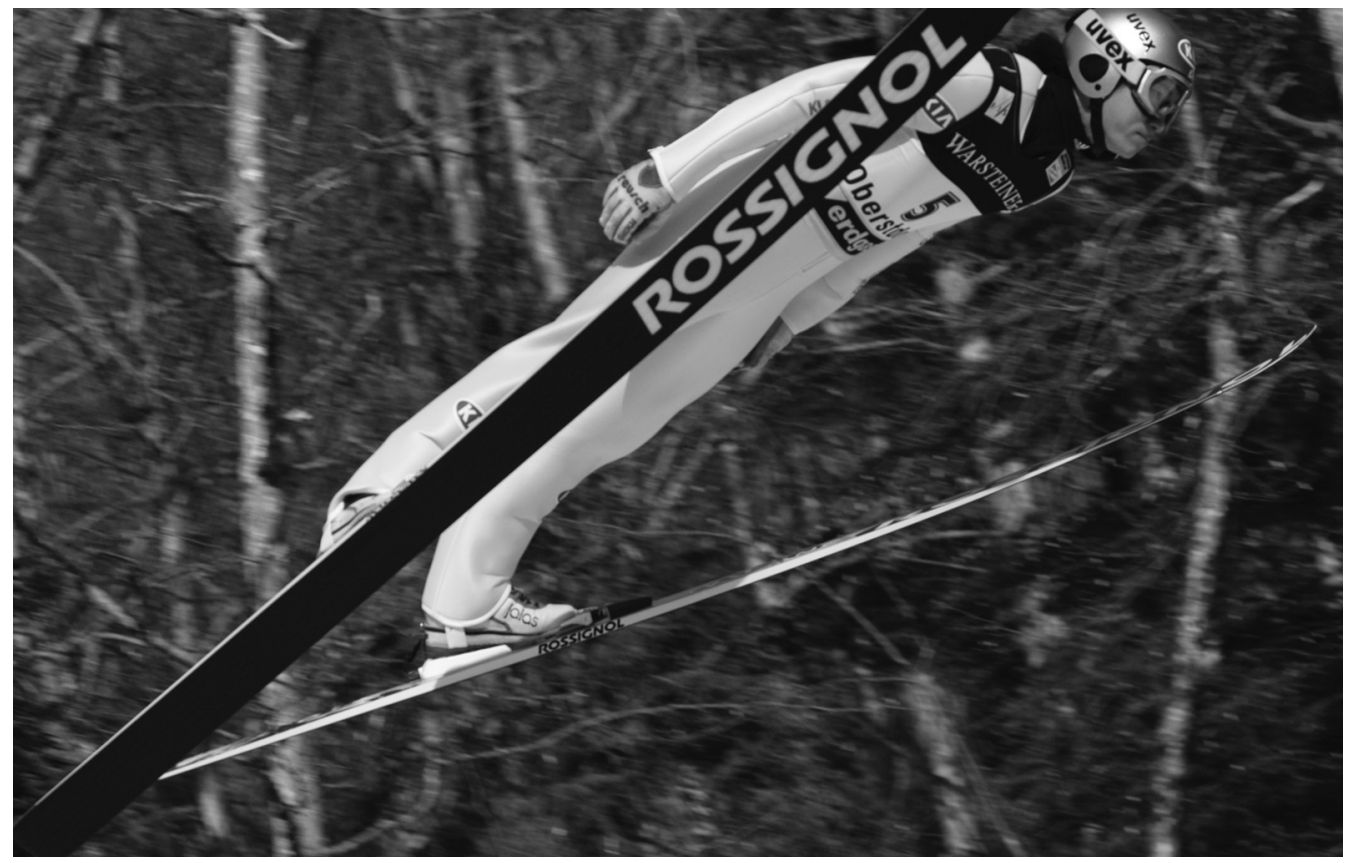

De traditionsrige skihopkonkurrencer fra Oberstdorf er en del af firebakketurneringen, hvor der også er konkurrencer i den tyske by Garmisch-Partenkirchen samt på to østrigske bakker, Innsbruck og Bischofshofen (Ulrich Dorner fot., Rass und Dorner GmbH Kitzbühel).

lands forbilledlige ørn snublede sig igennem Nytårsturneringen... modløs, energiforladt, fortvivlet $\omega^{55}$ Hannawald fremstilles som følsom, sårbar og ikke længere i stand til at håndtere forventningerne fra pressen og offentligheden.

Schmitt bliver i modsætning hertil fremstillet som »Mister Cool«, afslappet og med et godt humør, mindre modtagelig for presset fra omgivelserne og $\mathrm{i}$ stand til at håndtere både pressens bevågenhed og manglende sportslig succes. ${ }^{56}$ Han bliver betragtet som ligevægtig og med et drenget smil, som »åbenbart modstod belastningen, han blev udsat for $\ll .{ }^{57}$ Han indrømmer dog allerede i 2001 i et interview, at presset om at levere gode resultater er ved at blive for stort: »Jeg er kun et menneske [...] og på et eller andet tidspunkt kommer du til vejs ende. $1^{58} \mathrm{Schmitt}$ er trods dette fortsat aktiv i dag (2008), dog uden samme succes som tidligere. Men hans karriere er blevet dømt ovre flere gange, og »den forhenvarende super-ørn « måtte allerede i 2003 svare på spørgsmål som: »hvornår er dit nceste fald fra højderne, Hr. Schmitt? «"59 Jagten på årsagerne til »super-ørnens« tilbagegang fylder adskillige artikler ${ }^{60}$, f.eks. med denne (fejlagtige) konklusion i 2003 om, at Martin Schmitt er færdig. ${ }^{61}$

De to skihopperes angst, psykiske skrøbelighed og manglende evne til at modstå presset fremhæves i medierne, og medierne er dermed medvirkende til at konstruere images af skihopperne som mindre maskuline og heltemodige, images, som ikke lever op til de traditionelle maskulinitetsnormer, som skihopsporten som tidligere beskrevet historisk har repræsenteret. 


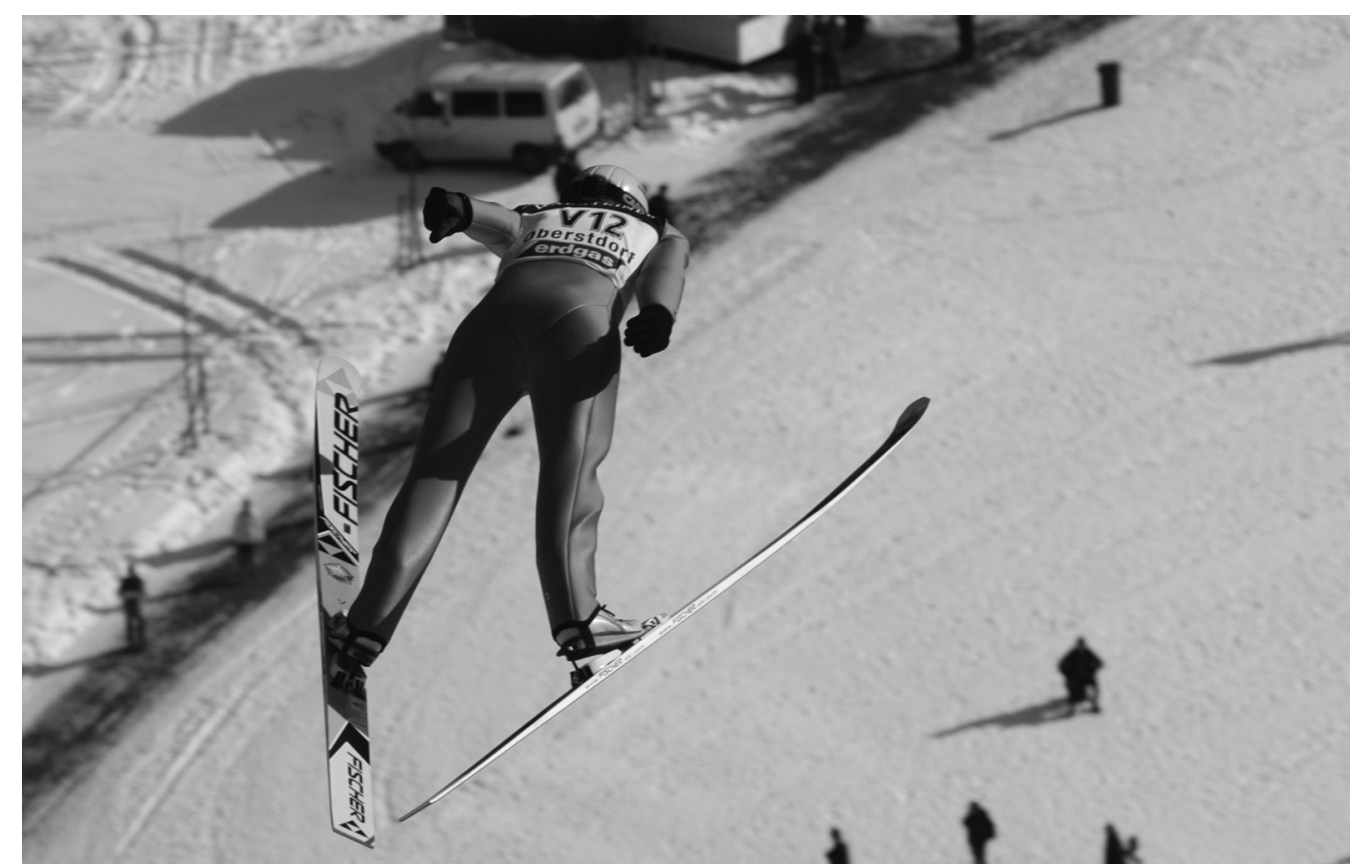

De tyske skihoppere sprang i 1990'erne ud som superstjerner. Skihopper på skihopbakken ved Oberstdorf (Ulrich Dorner fot., Rass und Dorner GmbH Kitzbühel).

\section{Skrøbelige helte: helt privat}

Som det er tilfældet med alle berømtheder, er medierne og publikum umættelige i deres ønske om viden om deres idoler, herunder viden om deres daglige og private liv. Begge udøvere, Schmitt mest i begyndelsen af karrieren og Hannawald helt til slutningen af sin karriere, portrætteres som pligtopfyldende og hjemlige typer med feminine træk og vaner. De bor hos deres forældre så længe som muligt, og de kommer fra familier med tætte bånd. ${ }^{62}$ Hannawald beskrives ofte som et »hjemmemenneske« og en eneboer. ${ }^{63}$ Hans hobbyer er at bage kager (han elsker islagkage), at lave mad, stryge, holde lejligheden ren og se TV om aftenen med sin bedste ven: fjernbetjeningen. ${ }^{64} \mathrm{Han}$ indrømmer, at han har få sociale kontakter, og at familien udgør hans sociale netværk. ${ }^{65}$ Under sine forskellige kriser søger han støt- te og råd hos sine forældre og især hos sin mor. ${ }^{66}$

Artikler om begge udøveres privatliv drejer sig ofte om »kæresteproblemet«. Der er mange overskrifter så som: »Hvornår vil Hanni og Nanni endeligt finde kcerester?", »Hvordan skal pigerne se ud? « og »Vil de ha' familie? « er almindelige ${ }^{67}$ Sport Bild præsenterer en smuk blondine, opremser hendes kvalifikationer såsom madlavningsevner og trofasthed efterfulgt af spørgsmålet: »Hanni, hvad synes du om hende? «68 TV-stationen RTL efterlyser på et tidspunkt interesserede kvinder og opfordrer dem til at ansøge om at blive Hannawalds kæreste. ${ }^{69}$

Kæreste-emnet har ofte seksuelle undertoner og bringer en vis tvivl om skihoppernes seksualitet på banen. »Schmitt har brug for en kcereste«, skriver Bild ${ }^{70}$ og antyder, at en mand uden en kvinde ikke er en rigtig 
mand. Tvivl om deres virilitet bliver også udtrykt gennem tilnavnet »luftens eunukker.$^{71}$ Bild spørger Hannawald åbent og direkte om hans seksuelle aktiviteter og får ham til at indrømme, at han ikke har haft nogen fysisk kontakt med en kvinde i meget lang tid. "Jeg har ikke kysset ordentligt $i$ over et år. Jeg har ikke engang savnet det", fortæller han Bild lige efter, at han er kommet sig ovenpå sin anoreksi. ${ }^{72}$ Da Schmitt og Hannawald endelig får kærester, kaster medierne sig over det nye emne ${ }^{73}$, og kæresterne Suska og Patricia dukker op i mange interviews uanset skihoppernes forsøg på at være diskrete.

Schmitt og Hannawald synes at acceptere mediernes nærgående adfærd. De stiller op til interviews også af mere personlig karakter og deler oplevelser og følelser med offentligheden. Mediernes fremstilling og vinkling har de ikke magt over, men det er tydeligt, at de forsøger at opretholde et godt forhold til pressen. Der er ikke i det analyserede materiale eksempler på, at skihopperne reagerer negativt på den måde, hvorpå medierne fremstiller dem. De synes i høj grad at se medierne som et sted at iscenesætte sig selv og deres sport og accepterer tilsyneladende betingelserne herfor.

\section{Skrøbelige helte, pinup drenge og teenager fans}

TV-transmissioner af skihopkonkurrencer tiltrækker et stort publikum, og Schmitt og Hannawald får en stor fanskare. Ud over fans med interesse i selve skihopsporten får Hannawald og Schmitt fat i et helt nyt fansegment, som er mere optaget af udøverne som personer end af sporten. Teenagere $i$ tusindvis begynder pludseligt at strømme til skihopbegivenheder eller følger deres heltes succeser og fiaskoer i medierne.
Der synes at eksistere et ambivalent forhold mellem stjernerne og deres fans, hvilket er et hyppigt emne i de analyserede artikler. På den ene side giver stjernerne udtryk for at være stolte af at være genstand for deres fans' opmærksomhed. Fansene giver støtte og opbakning, og er desuden potentielle kunder for sponsorerne, som bruger stjernerne og deres image til at sælge deres produkter. På den anden side skaber fans et pres, ikke kun for at udøverne skal vinde konkurrencer, men også for at de skal give en modydelse eksempelvis $i$ form af autografskrivning. Det sker også, at fanskarerne bliver potentielt farlige, hvorfor der ansættes bodyguards til at beskytte skihopperne fra tusindvis af skrigende og hysteriske piger, som kaster tøjdyr efter deres idoler eller forsøger at røre eller omfavne dem. ${ }^{74}$ Martin Schmitt fortæller Bild, at »jeg er glad for alle mine fans, men jeg kan ikke skrive autografer til alle, og jeg kan ikke lade allesammen rore ved mig «. ${ }^{75}$

Fankulturen omkring Hannawald og Schmitt ligner således mere og mere den kultur, som udspiller sig omkring popidoler. Den har som vist ovenfor både positive og negative aspekter for de to skihoppere. I de følgende afsnit vil vi diskutere, hvad denne udvikling betyder for skihoppernes image, og hvordan fanskarerne påvirker den forhandling og konstruktion af image og maskulinitet, som finder sted i medierne.

\section{Skihop og ambivalent maskulinitet}

Den nye generation af skihoppere, eksemplificeret af Hannawald og Schmitt tiltrækker med deres drengede udseende og seksualiserede images især et publikum af 


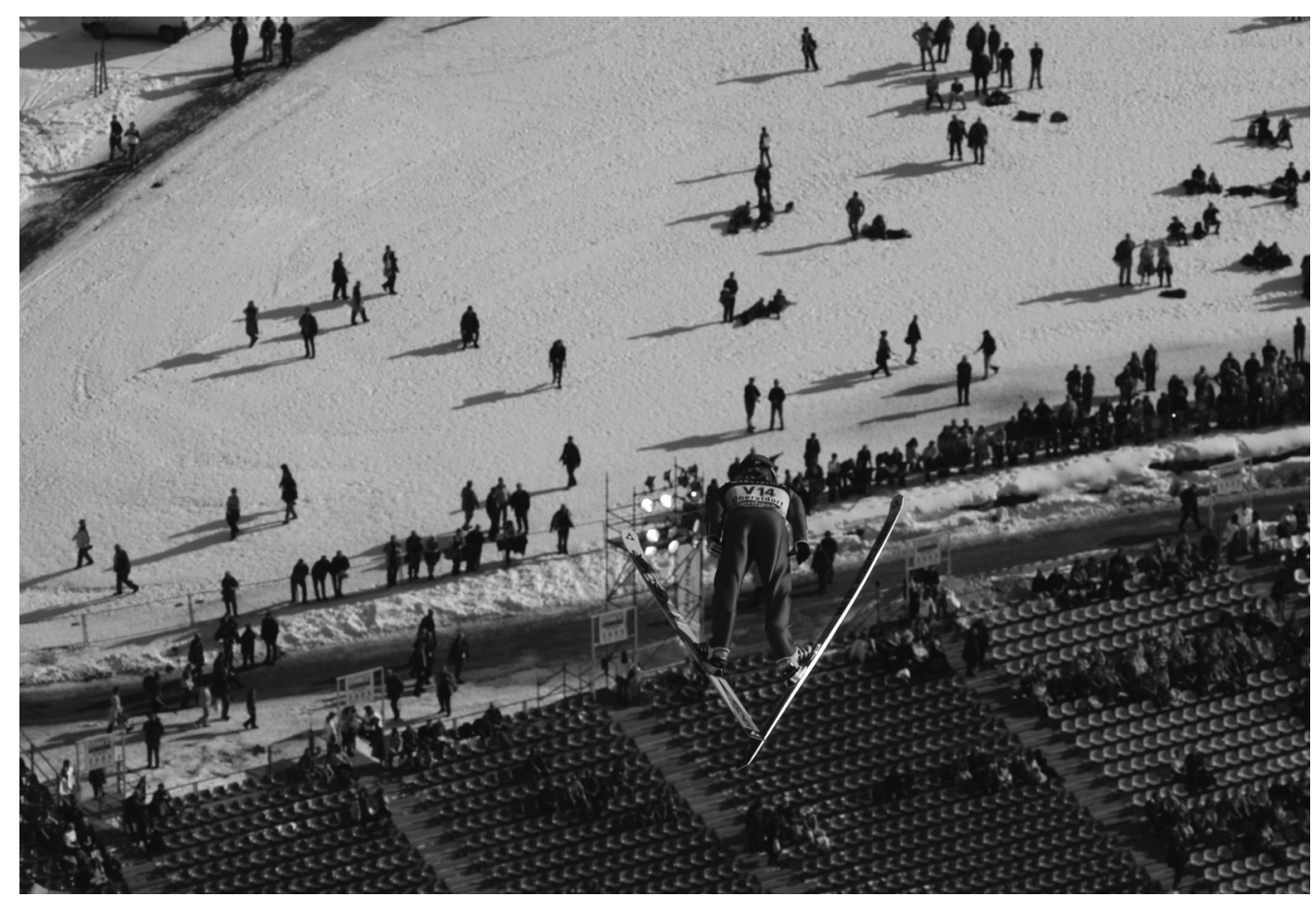

Skihop-konkurencen i den sydtyske by er den mest prestigefyldte i skihop-scesonen, og alle skisports-historiens store navne har stået øverst på sejrspodiet i Oberstdorf (Ulrich Dorner fot., Rass und Dorner GmbH Kitzbühel).

teenagepiger. De kvindelige fans tilbeder stjernerne, som ifølge Bild »hoppede ind $i$ deres hjerter « ${ }^{76}$ De diskuterer idolerne og udveksler sensuelle billeder af dem over internettet. ${ }^{77}$ Nogle fans gør åbenlyse seksuelle tilnærmelser, såsom en flok groupier ved pisten, som bærer skilte med udsagn som »Martin, jeg vil have et barn med dig", »Hanni, hvad skal du på fredag?" eller »Hanni, du er så sexet . $^{78}$ Skihopperne er genstand for et kvindeligt blik, og medierne afbilder dem som objekter for kvinders begær og som sexidoler. ${ }^{79}$ Modsat i traditionelle kønsregimer er pigerne mere aktive i en jagt, hvor udøverne bliver beskrevet som ganske passive og ikke synderligt interesserede i det andet køn. »Jeg er ingen Don Juan«, fortalte Schmitt i et interview i Bild am Sontag. ${ }^{80}$
Det tilbagevendende tema i pressen om manglende kærester kan betragtes som udtryk for den hetero-normalitet, som findes i sporten såvel som i resten af samfundet. ${ }^{81}$ En kæreste ville kunne bekræfte skihopperens normalitet; læs heteroseksualitet. Det gælder især for Hannawald, hvis udseende, tøjstil og singlestatus er anledning til rygter om hans mulige homoseksuelle orientering. ${ }^{82}$ Hannawald beskrives som en $» b l ø d$ mand « med interesse for traditionelt kvindelige aktiviteter som bagning og skønhedsprodukter. Derudover går han på slankekure og lider af anoreksi, der oftest betragtes som en sygdom, der rammer piger. Hannawald er en diametral modsætning til den store alpine skiløber, Hermann Meier, som med tilnavnet »Herminatoren «, var en 
arketypisk alfa-han kendetegnet af brutal ambition og vindermentalitet. ${ }^{83}$

Skihoppernes maskulinitet bliver fremstillet - af dem selv og af medierne - som modsætningsfyldt, ambivalent og omstridt, og den adskiller sig fundamentalt fra det traditionelle ideal om den stærke, frygtløse og seksuelt aktive mandlige sportshelt. Men er det netop denne ambivalens, der gør skihopperne så tiltrækkende for teenagepiger? Det er i hvert fald Bilds forklaring; »På den ene side har vi skihopperne, som trodser døden igennem deres ekstremsport. På den anden side er de stadig drenge med blide traek [...] derfor ser mange Hannawald som deres drømmeprins. $\aleph^{84}$

På den baggrund kan man sige, at V-stilens skihoppere har tiltrukket nye fans og sammen med massemedierne har skabt en ny type maskulinitet, der kombinerer en helt og en genert ung mand. Skihopperne bliver objektiverede og seksualiserede af fanskarerne og får tildelt en passiv rolle $\mathrm{i}$ dette 'spil' i medierne. Kombinationen af helt og genert ung mand lader fans beundre genstanden for deres begær, men lader dem også spille en aktiv rolle i deres imaginære forhold. Dette vender om på traditionelle forestillinger om manden som den aktive forfører og kvinden som den passive modtagende part i et kønsspil og påvirker derved udøvernes image ved at rejse tvivl om deres maskulinitet.

\section{Konklusion}

I det seneste årti er skihop/skiflyvning blevet fornyet i forhold til teknikker, udstyr, image og fans. En af de drivende kræfter bag forandringerne er sportens centrale rekordprincip; et princip, som lægger et konstant pres på skihopperne om at forbedre deres præstationer, men som også afsted- kom opdagelsen en ny hoppeteknik, der kunne indfri kravet om stadigt længere hop. V-stilen har ikke kun forandret skihoppernes kroppe, men også deres personlighed, images og praktisering af køn. En ny type skihoppere har taget podiet, og massemedierne har spillet en vigtig rolle i konstruktionen og præsentationen af nye images og maskulinitetsformer. Skihopperne kan ikke længere opretholde et image som maskuline og muskuløse vovehalse, der ikke viser følelser og er upåvirkede af farer og potentielle fejltrin. Herigennem har nye ambivalente blandingsformer af mod og angst, følsomhed og mental styrke udviklet sig. Skihoppere af i dag er såvel »ørne« som »lopper«.

De særlige relationer mellem sportsforbund, arrangører af sportsbegivenheder, skihoppere, fans og sponsorer er kun mulig, fordi medierne udover at levere information også tilbyder materiale til drømme og fantasier. Medierne er en scene for selvpræsentation og konstruktion af maskulinitet og for at praktisere køn.

Medierne har gjort skihop til en glamourøs mediesport, hvor skihopperne på godt og ondt fremstilles som idoler, specielt for teenagepigerne. Medierne og markedet har skabt nye images for udøverne, som er tilpasset deres fans' smag og sponsorernes behov, men de har også været med til at skabe images, som rummer ambivalente budskaber i forhold til maskulinitet, seksualitet, udseende og adfærd. På den ene side fremstilles udøverne fortsat som helte, der trodser naturlovene og udviser dødsforagt. På den anden side passer skihoppernes kroppe, livsstil, frygt og nerver ikke rigtigt til de traditionelle mandeidealer. Medierne præsenterer skihoppernes image med en ambivalent maskulin udstråling, hvor der sås tvivl om både seksuel orientering og vi- 


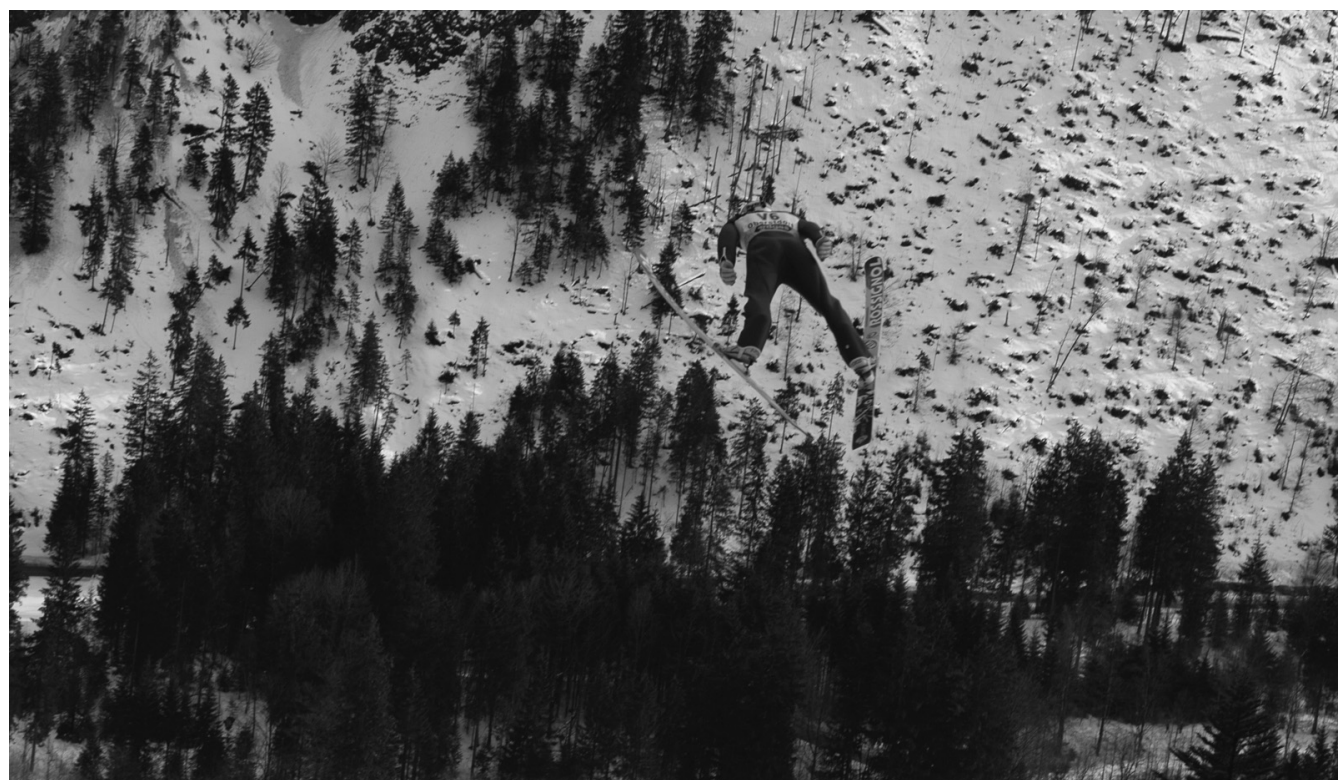

Højt over trceerne svcever skihopper, når der er konkurrence på skihopbakken i Oberstdorf (Ulrich Dorner fot., Rass und Dorner GmbH Kitzbühel).

rilitet. Hvis man betragter mediedækningen af sportsgrenen og skihoppernes images før og efter V-stilens opkomst, kan man stille spørgsmål ved, hvorvidt rammerne i den medierede sportsverden for adfærd og udfoldelse af maskulinitet er blevet bredere, smallere eller mere normative?

Kontrasten mellem de gamle sportshelte og de nye sportsstjerner er skarp, men det er ikke mindst tilfældet, fordi medierne i dag zoomer ind på udøvernes svagheder og endevender deres liv. Vilkårene og spillet mellem medier og sportsstjerner er anderledes $\mathrm{i}$ dag, hvor stjernerne ikke kan nøjes med at give offentligheden indblik i deres sportslige praksis, men også må stille op til interviews, som omhandler det hele menneske på godt og ondt, og ydermere må se sin iscenesættelse og praktisering af køn blive fortolket af medierne på måder, som tidligere ville vække forargelse. Svagheder og feminine træk fremhæves og latterliggøres i visse tilfælde, og udøverne bliver ofte be- tragtet og præsenteret som umodne drenge. Mediernes dækning er ambivalent og kan ses som udtryk for, at de nye maskulinitetsformer opfattes som problematiske, men kan også ses som udtryk for, at det i dag er accepteret at diskutere følsomme emner som angst, depression, seksuel orientering og maskulinitet, og derfor kommer det også med i mediediskursen omkring sportsstjerner som Hannawald og Schmitt. De modsætningsfyldte maskulinitetsformer, som de repræsenterer, er således også et udtryk for forandringer i den gældende kønsorden, hvor de kønnede regimer udfordres blandt andet gennem mediediskurser som denne.

Medierne har derudover været med til at sætte fokus på problematiske tendenser i sporten, såsom forekomsten af anoreksi, angst og udbrændthed. Medierne har dog ikke analyseret sin egen rolle heri, og man kan argumentere for, at medierne har deres del af ansvaret for, at presset på stjernerne har været en medvirkende faktor til at ud- 
løse eller forværre deres psykiske problemer.

Medierne kan siges at være motor for den moderne sports fokusering på rekorder, og drømmen om og afhængigheden af den ultimative præstation er drivkraften bag både heltemod og udbrændthed.

\section{Postscript - maskuliniteten reddet?}

Skihoppernes truede kroppe har fået det internationale skiforbund (FIS) til at etablere regler, som reducerer fordelene ved at være lille og let. ${ }^{85}$ En af reglerne er, at skienes længde skal tilpasses skihopperens højde. Mindre udøvere skal i dag hoppe med kor- tere ski, ${ }^{86}$ hvilket har medført at høje udøvere har forsøgt at tabe sig, så de kan udnytte fordelene ved at have længere ski. Som reaktion på denne strategi har FIS indført BMI (Body Mass Index) grænseværdier om, at udøvere under en vis vægt skulle have kortere ski.

Hensigten med disse regler var blandt andet at forbedre skihopsportens image, som var blevet skadet af anoreksidebatten og skihoppernes tydeligvis magre kroppe. ${ }^{87}$ Med regelændringerne ville man vise offentligheden, at »systemet ønsker at belønne atletiske sportsmaend igen $\ll{ }^{88}$ Det er stadig for tidligt at sige, om skihoppernes image som skrøbelige helte vil blive udskiftet med en anden præsentation af maskulinitet.

\section{Noter}

1 For mere om kvinders skihophistorie se Preuss A. Anfänge und Entwicklung des Frauenskispringens. upubliceret specialeafhandling (Münster, 2005); Hofmann A \& Preuss A. Amazonen der Lüfte: Geschichte und Entwicklungen im Frauenskispringen. I: Internationale Skihistoriographie und deutscher Skilauf, redigeret af: Deutscher Skiverband, (2005), pp. 105-114; von der Lippe G. Ski Jumping. I: International Encyclopedia of Women and Sport. Christensen K, Guttmann A \& Pfister G. (red.) (New York, 2001).

2 Lorber J \& Moore L J. Gendered Bodies: Feminist Perspectives (Los Angeles, 2007), p. 5.

3 West C \& Zimmerman D H. Doing Gender. I: Gender \& Society. 1987 - (1), pp. 125-151; West C \& Zimmerman D H. Doing Difference. I: Gender \& Society. 1995 - (9), pp. 8-37.

4 Connell R W. Masculinities and Globalisation. I: Kvinder, Køn \& Forskning 1999 - (3), pp. 43-60; Jørgensen A S. Drengestreger. Studier i drenge, mand og maskulinitet. I: Kvinder, Køn \& Forskning 1999 - (3), pp. 61-70.

5 Lorber J \& Moore L J. Gendered Bodies: Feminist Perspectives (Los Angeles, 2007), p. 2.

6 På trods af at der er lavet utallige studier om kvin-

de- og kvindelighedshistorie, (se eksempelvis Pfister G. Die andere Perspektive: Frauenforschung und Sportgeschichte. I: Stadion 1990 - (16), pp. 143-169), var det først i 1990'erne at interessen for mande- og maskulinitetshistorie tog til og studier begyndte at blive publiceret. Se eksempelvis Bonde H. Mandighed og Sport. (Odense, 1991); Kühne T. (red.): Männergeschichte - Geschlechtegeschichte, Männlichkeit im Wandel der Moderne. (Frankfurt am Main/New York,1996); Mosse G L. The image of man: the creation of modern masculinity. (New York, 1996), eller specialudgaven af Kvinder, Køn \& Forskning 3 (1999).

7 Connell R W. Gender (Cambridge, 2002), p. 47.

8 Loland N W. Some contradictions and tensions in elite sportsmen's attitudes towards their bodies. I: International Review for the Sociology of Sport, Vol. 34, 1999 - (9), pp. 291-302.

9 Mosse G L. The image of man: the creation of modern masculinity. (New York, 1996); Whannel G. Media Sport Stars. Masculinities and Moralities. (London/New York, 2002).

10 Whannel G. Media Sport Stars. Masculinities and Moralities. (London/New York, 2002). 
11 For skihophistorie, se: Jahn J \& Theiner E. Enzyklopädie des Skispringens. (Kassel: 2004).

12 Allen J. From Skisport to Skiing: One Hundred Years of an American Sport, 1840-1940. (Amherst, 1993); Jahn J \& Theiner E. Enzyklopädie des Skispringens (Kassel, 2004); Der Winter (1923:8), p. 112.

13 Allen J. From Skisport to Skiing: One Hundred Years of an American Sport, 1840-1940. (Amherst, 1993). Allen beskriver også skihops oprindelse i Europa.

14 Citeret i Jeschko K. Silberne Pisten - Goldener Lorbeer. (Wien, 1964), p. 16

15 Der Winter (1923:8), p. 112.

16 Der Winter 1921, Vol. 1, 5.

17 For skihop historie med særligt fokus på teknik, se http://de.wikipedia.org/wiki/SkisprungTechnik (gennemset 3. nov. 2006). Se ligeledes »Skisprung-Geschichte 1876-2006« .http:// www.4schanzentournee.com/CMS Files/68 item.asp?root_id=27\&node_id=68\&item_id=11 (gennemset 3. okt. 2006).

18 Jahn J \& Theiner E. Enzyklopädie des Skispringens (Kassel, 2004), p. 249.

19 Der Spiegel (2002:52), p. 22.

20 Mayring P. Qualitative Content Analysis. I: Qualitative Social Resears, Volume 1, 2000-(2), http://www.qualitative-research.net/fqs texte/ 2-00/2-00mayring-e.htm

21 Der Spiegel (2002:52), p. 122.

22 Bild (20. dec. 2000).

23 Welt (12. feb. 2000).

24 http:/dpoportall.diepresse.apa.net/home/sport/ wintersport/293009/index.do (gennemset 12.03.08).

25 Welt (11. feb. 2000).

26 Bild (30. dec. 2000); Der Spiegel (1998:51), p. 239; Bild (5. feb. 2000)

27 Der Spiegel (2001:9), p. 157; (2002:54), p. 28

28 Der Spiegel (2002:48), p. 122

29 Se Sport Bild (16. jan. 2002) for en biografi af Hannawald med de fleste af emnerne som diskuteres i denne artikel, fra anoreksi til forholdet til hans forældre og kæresteproblemer.

30 Bild (15. feb. 2000).

31 Originaltitel på engelsk er St. Clare's og handler om to piger, tvillingerne Nanni og Hanni. Bogserien er skrevet af Enid Blyton.

32 Der Spiegel (1999:469), p. 254; (2002:48), p. 122; Bild (3. jan. 2002).

33 Der Spiegel (2002:52), p. 122.

34 Der Spiegel (2004:20), p. 132.

35 Der Spiegel (2004:20), p. 132.
$36 \operatorname{BamS}$ (10. nov. 2002).

37 Se eksempelvis Der Spiegel (1998:51), p. 239; Bild (3. jan. 2002).

38 Bild (23. jan. 2002).

39 Bild (3. jan. 2000).

40 se eksempelvis Welt (10. jan. 2004).

41 Bild trykte billedet sammen med et interview med Hannawald om anoreksi (10. nov. 2000). Se også Bild (3. jan. 2002).

42 Der Spiegel (2004:20), p. 132.

$43 \operatorname{BamS}$ (10. nov. 2002).

44 Bild (3. jan. 2000).

45 Welt (12. feb. 2000).

46 Welt (12. feb. 2000).

$47 \operatorname{WamS}$ (15. feb. 2004).

48 WamS (15. feb. 2004).

$49 \operatorname{WamS}$ (25. nov. 2001).

50 Bild (10. feb. 2000).

51 se eksempelvis Sport Bild (7. jan. 2004).

52 Welt (16. feb. 2000)

53 Der Spiegel (1999:51), p. 178.

54 Bild (24. nov. 2004); Der Spiegel (2004:20), p. 132.

55 Sport Bild (7. jan. 2004).

56 Bild (15. feb. 2000); (21. feb. 2001): (20. dec. 2002); Welt (3. jan. 2002).

57 WamS (24. dec. 2000).

58 Bild (8. jan. 2001). Se også Bild (28. feb. 2003) om nærgående fans, det intensive pres lagt på udøverne og deres følelse af at blive skubbet 'ud til grænsen'.

$59 \operatorname{BamS}$ (23. jan. 2003).

60 Se f.eks. Sport Bild (15. dec. 2004).

61 Bild (28. feb. 2003).

62 BamS (18. nov. 2001); (6. jan. 2002).

63 Der Spiegel (2004:20), p. 132.

64 Bild (7. jan. 2002); Der Spiegel (2002:48), p. 122.

65 WamS (28. dec. 2003).

66 Bild (10. nov. 2000); (24. nov. 2004); Welt (11. mar. 2002).

67 WamS (19. nov. 2000); (25. jan. 2001).

68 Sport Bild (16. jan. 2002).

69 Der Spiegel (2002:48), p. 122.

70 Bild (28. feb. 2001).

71 Schlehahn B. Widerspenstige männliche Körper. Die Konstruktion von körperlicher Männlichkeit im Skispringen. Bidrag ved konferencen: 3. Tagung des Arbeitskreises für interdisziplinäre Männer- und Geschlechterforschung (24.-26. Juni 2004), p. 2, http://66.102.9.104/search?q=cache: o8FrwXvMGVIJ:www.ruendal.de/aim/tagung04/ pdfs/britt_schlehahn.pdf + schlehan + skispringen $\& \mathrm{hl}=\mathrm{de} \& \mathrm{ct}=\mathrm{clnk} \& \mathrm{~cd}=1$ (gennemset 12.03 .08$)$ 
72 Bild (10. nov. 2000).

73 WamS (2. nov. 2003).

74 Der Spiegel (2002;48), p. 122; Welt (6. jan. 2004).

75 Bild (5. feb. 2000).

76 Bild (18. jan. 2002).

77 På en blog om udbrændthed diskuteres rygterne om Hannawalds seksuelle præferencer: http:// www.ichkannsonichtarbeiten.net/blog/index. php/archives/2005/05/23/sven-hannawald-beibeckmann/ (gennemset 10. mar. 2008).

78 Bild (18. jan. 2002), (28. feb. 2003).

79 Bild (18. jan. 2002).

$80 \operatorname{BamS}$ (18. nov. 2001).

81 Whannel G. Media Sport Stars. Masculinities and Moralities. (London/New York, 2002), p. 28.

82 Der Spiegel (2004:20), p. 132.

$83 \mathrm{http} / / /$ en.wikipedia.org/wiki/The Herminator (gennemset 13.03.08).
84 Bild (18. jan. 2002).

85 Se WamS (11. feb. 2004); Sport Bild (7. jan. 2004).

86 Skiene må maksimalt måle 146 \% af udøverens højde.

87 Schlehahn B. Widerspenstige männliche Körper. Die Konstruktion von körperlicher Männlichkeit im Skispringen. Bidrag ved konferencen: 3. Tagung des Arbeitskreises für interdisziplinäre Männer- und Geschlechterforschung (24.-26. Juni 2004), p. 3, http://66.102.9.104/search?q=cache: o8FrwXvMGVIJ:www.ruendal.de/aim/tagung04/ pdfs/britt_schlehahn.pdf+schlehan+skispringen $\& \mathrm{hl}=\mathrm{de} \& \mathrm{ct}=\mathrm{clnk} \& \mathrm{~cd}=1$ (gennemset 12.03.08).

$88 \operatorname{WamS}$ (20. aug. 2000). 